Arq. Bras. Med. Vet. Zootec., v.67, n.4, p.951-960, 2015

\title{
Epidural levobupivacaine alone or combined with different morphine doses in bitches under continuous propofol infusion
}

\author{
[Levobupivacaína isolada ou associada à morfina em diferentes doses pela via \\ peridural em cadelas sob infusão contínua de propofol] \\ V.B. Albuquerque ${ }^{1}$, M.A. Araújo ${ }^{2}$, G.T.N.M. Ferreira ${ }^{3}$, M.W. Fonseca ${ }^{4}$, \\ C.J.X. Abimussi ${ }^{5}$, J.Z. Ferreira ${ }^{5}$, V.N.L.S. Oliva ${ }^{6}$ \\ ${ }^{1}$ Pesquisadora Fundect/CNPq Nível C - UFMS - Campo Grande, MS \\ ${ }^{2}$ Faculdade de Medicina Veterinária e Zootecnia - UFMS - Campo Grande, MS \\ Aluno de pós-graduação - Unesp - Araçatuba, SP \\ ${ }^{3}$ Médico veterinário autônomo \\ ${ }^{4}$ Programa de residência - Unesp - Botucatu, SP \\ ${ }^{5}$ Aluno de pós-graduação - Unesp - Araçatuba, SP \\ ${ }^{6}$ Faculdade de Medicina Veterinária - Unesp - Araçatuba, SP
}

\begin{abstract}
The aim of this study was to assess the cardiopulmonary, analgesic, adverse effects, serum concentration of cortisol and plasma levels of levobupivacaine and morphine in bitches undergoing propofol anesthesia and epidural analgesia with levobupivacaine alone or combined with morphine. This was a randomized 'blinded' prospective clinical study using 32 adult bitches weighing $9.8 \pm 4.1 \mathrm{~kg}$ that were admitted for elective ovariohysterectomy. Twenty minutes after administration of acepromazine and midazolam, anesthesia was induced with propofol $\left(4 \mathrm{mg} \mathrm{kg}^{-1}\right)$ and maintained by a continuous rate infusion (CRI). Each animal was randomly assigned to one of four epidural groups: $\mathrm{GL}=$ levobupivacaine alone $\left(0.33 \mathrm{mg} \mathrm{kg}^{-1}\right)$; GLM0.1 = levobupivacaine and morphine $\left(0.1 \mathrm{mg} \mathrm{kg}^{-1}\right)$; GLM0.15 = levobupivacaine and morphine $\left(0.15 \mathrm{mg} \mathrm{kg}^{-1}\right)$; and GLM0.2 = levobupivacaine and morphine $\left(0.2 \mathrm{mg} \mathrm{kg}^{-1}\right)$. Variables obtained during anesthesia were heart rate, respiratory rate, systolic, mean and diastolic arterial blood pressures, oxyhemoglobin saturation, inspired oxygen fraction, end-tidal carbon dioxide tension, blood gases, serum cortisol, and plasma levels of levobupivacaine and morphine. The onset and duration times of the blockade were recorded. Arterial pressures were significantly increased in all groups at the times of ovarian pedicle clamping. There was a decrease in $\mathrm{pH}$, together with an increase in both $\mathrm{PaO}_{2}$ and $\mathrm{PaCO}_{2}$ over time. Serum cortisol levels were increased in TESu compared to TB, T30 and TR. Limb spasticity, muscle tremors, opisthotonos and diarrhea were observed in some animals during propofol infusion and ceased with the end of CRI. Reactions happened at different moments and lasted for different periods of time in each individual. Epidural with levobupivacaine alone or combined with morphine allowed for ovariohysterectomy to be performed under low propofol infusion rates, with minimal changes in cardiovascular variables and in serum cortisol levels. Adverse effects were observed in very few animals in each group.
\end{abstract}

Keywords: dog, opioid, ovariohysterectomy, blood gas, regional anaesthesia

\section{RESUMO}

Objetivou-se avaliar os efeitos cardiovasculares, analgésico, adversos, a concentração sérica de cortisol e os níveis plasmáticos de levobupivacaína e morfina em cadelas submetidas à infusão contínua de propofol e analgesia peridural com levobupivacaína isolada ou associada à morfina. Para tanto, realizou-se um estudo clínico prospectivo randomizado com 32 cadelas adultas pesando 9,8 4,1 kg, que foram submetidas à ováriohisterectomia eletiva. Vinte minutos após a administração de acepromazina e midazolam, os animais foram induzidos com propofol (4mg/kg) e mantidos por uma infusão contínua (CRI) do mesmo fármaco. Cada animal foi alocado aleatoriamente em um dos quatro grupos: $G L=$ levobupivacaína isolada $(0,33 \mathrm{mg} / \mathrm{kg}) ; \mathrm{GLMO}, 1=$ levobupivacaína + morfina $(0,1 \mathrm{mg} / \mathrm{kg}) ;$ GLM0,15 = levobupivacaína + morfina $(0,15 \mathrm{mg} / \mathrm{kg})$ e GLM0,2 = levobupivacaína + morfina $(0,2 \mathrm{mg} / \mathrm{kg})$. As variáveis obtidas durante a anestesia foram FC, $f, P A S$, PAM e

Recebido em 16 de maio de 2014

Aceito em 27 de março de 2015

E-mail: voliva@fmva.unesp.br 
PAD, SaO2, FiO2, EtCO2, gases sanguíneos, cortisol sérico e os níveis plasmáticos de levobupivacaína e morfina. Foram analisados, ainda, os períodos de latência e a duração dos bloqueios. As pressões arteriais aumentaram significativamente em todos os grupos nos momentos de ligadura dos pedículos ovarianos. Houve uma diminuição do $\mathrm{pH}$, em conjunto com um aumento da $\mathrm{PaO} 2$ e da $\mathrm{PaCO} 2$ ao longo do tempo. Os níveis séricos de cortisol aumentaram. Espasticidade de membros, tremores musculares, opistótono e diarreia foram observados em alguns animais. Tais reações aconteceram em diferentes momentos e duraram diferentes períodos de tempo em cada indivíduo. A anestesia peridural com levobupivacaína isolada ou associada à morfina permitiu ovário-histerectomia em cadelas sob infusão de propofol, com mínimas alterações nas variáveis cardiovasculares e nos níveis de cortisol sérico e com baixo índice de efeitos adversos.

Palavras-chave: cão, opioides, ovariohisterectomia, concentração plasmática, anestésicos locais

\section{INTRODUCTION}

Levobupivacaine is the S-enantiomer of bupivacaine and clinical protocols for humans suggest that its potency is similar to that of bupivacaine (Vladimirov et al., 2000). An experimental study showed that levobupivacaine causes less toxic effects such as seizures, arterial hypotension, apnea and circulatory collapse when compared to bupivacaine in sheep (Santos e DeArmas, 2001).

In a study by Segura et al. (2009) there was no evidence of important adverse effects with epidural levobupivacaine in dogs. However, the reports concerning the use of levobupivacaine are still scarce, leaving some of its effects, onset time, duration of the anesthesia and incidence of adverse reactions yet to be described.

In this context and with the constant search for new techniques for balanced anesthesia, we often observe the use of opioids with local blocks, whether eith the pre-operative or at the postoperative medications. The main goal of the association with a local anesthetic is analgesia as well as reduction of the dose of anesthetics, providing comfort for patients.

Morphine is widely used in veterinary medicine. It can contribute for minimizing hyperglycemia as well as the release of cortisol and catecholamines that happen in response to pain. This effect has been demonstrated in bitches premedicated with morphine and undergoing ovariohysterectomy or laparotomy (Lucas et al., 2001). The combination of morphine and local anesthetics through the epidural route can increase the duration of the block, as well as its analgesic efficacy.

Therefore, the purpose of this study was to investigate the cardiorespiratory and analgesic effects, incidence of adverse reactions and serum concentrations of cortisol of bitches undergoing constant rate infusion (CRI) of propofol and epidural anesthesia with levobupivacaine alone or combined with morphine at $0.1,0.15$ and $0.2 \mathrm{mg} \mathrm{kg}^{-1}$ for elective ovariohysterectomy.

We hypothesized that levobupivacaine combined with morphine in higher doses $(0.15$ and $0.2 \mathrm{mg}$ $\mathrm{kg}^{-1}$ ) would enable the surgery to be performed under continuous infusion rate propofol of $0.4 \mathrm{mg}$ $\mathrm{kg}^{-1}$ minute $^{-1}$ without causing significant cardiovascular changes, adverse effects or increases in serum cortisol.

\section{MATERIAL AND METHODS}

The study was approved by the local Animal Care and Use Committee (protocol no. 0043912009). Thirty-two healthy young adult bitches of various breeds and ages, weighing 9.8 to $4.1 \mathrm{~kg}$, undergoing elective ovariohysterectomy were included in the study. All animals, after proprietary consent, went through a physical examination, electrocardiogram (ECG) (TEB C10 - ECG, Brazilian Electronic Technology Ltda., Brazil), complete blood cell count, and biochemical analyses (kidney and liver enzymes) before the procedures.

Subjects were fasted for 12 hours and water withheld for four hours before anesthesia. A new physical examination was performed (pre-anesthesia), to record baseline variables $(\mathrm{TB})$ : respiratory rate $\left(\mathrm{f}_{\mathrm{R}}\right)$, heart rate (HR), electrocardiogram (ECG), noninvasively measured systolic, mean and diastolic arterial pressures (SAP, MAP and DAP respectively) (Mod Cardiocap 5 Datex Ohmeda process Fapesp 2005/00858-9, Brazil) and drawing of venous blood from the jugular vein for serum cortisol concentration through radioimmunoassay. Premedication was given intramuscularly with $0.05 \mathrm{mg} \mathrm{kg}^{-1}$ acepromazine 
(Acepran 0.2\% - acepromazina - Univet S/A Ind. Vet., Brazil) and $0.2 \mathrm{mg} \mathrm{kg}^{-1}$ midazolam (Dorrmire - midazolam 5mg $\mathrm{mL}^{-1}$ - Cristália chemicals and pharmaceuticals Ltda., Brazil).

After 20 minutes variables were again recorded (T20) and the right cephalic vein was catheterized for fluid administration $(0.9 \% \mathrm{NaCl}$ at $10 \mathrm{~mL} \mathrm{~kg}^{-1}$ hour $^{-1}$ ). Propofol (Propovan propofol $10 \mathrm{mg} \mathrm{mL}^{-1}$ - Cristália chemicals and pharmaceuticals Ltda., Brazil) was given through the left cephalic vein. Induction of anesthesia was accomplished with a $4 \mathrm{mg} \mathrm{kg}^{-1}$ bolus of propofol followed by maintenance at initially 0.4 $\mathrm{mg} \mathrm{kg}^{-1}$ minute ${ }^{-1}$ CRI given by a syringe pump. Animals were intubated and kept under $100 \%$ inspired oxygen fraction $\left(\mathrm{FiO}_{2}=1.0\right)$ breathing spontaneously (Ferro et al., 2005; Gasparini et al., 2009).

With the dogs in prone sphinx position, the hair was clipped and the skin was prepared for aseptic insertion of a spinal needle (Perican 22G, BBraun, Brazil) at the lumbosacral space $\left(\mathrm{L}_{7}-\mathrm{S}_{1}\right)$. The needle was inserted through the intervertebral space until it reached below the interarcuate ligament to the epidural space.

Animals were randomly assigned to four groups of eight subjects each, as follows: $\mathrm{GL}=$ levobupivacaine (Novabupi levobupivacaine $7.5 \mathrm{mg} \mathrm{mL} \mathrm{mL}^{-1} \quad$ Cristália chemicals and pharmaceuticals Ltda., Brazil) alone $\left(0.33 \mathrm{mg} \mathrm{kg}^{-1}\right)$; GLM0.1 = levobupivacaine and morphine (Dimorf - morphine $10 \mathrm{mg} \mathrm{mL}^{-1}$ Cristália chemicals and pharmaceuticals Ltda., Brazil) (0.1mg $\left.\mathrm{kg}^{-1}\right)$; GLM0.15 = levobupivacaine and morphine $\left(0.15 \mathrm{mg} \mathrm{kg}^{-1}\right)$; and GLM0.2 = levobupivacaine and morphine $\left(0.2 \mathrm{mg} \mathrm{kg}^{-1}\right)$. To all groups except GL, levobupivacaine was added up to a final volume of $0.3 \mathrm{~mL} \mathrm{~kg}^{-1}$.

Following epidural anesthesia, which was injected over one minute (Valadão et al., 2002), animals were kept in sternal recumbency for another 30 minutes so that drugs would distribute equally to both sides. During this time all the monitoring equipment and sensors were placed. The dog was then turned into dorsal recumbency and the midline was clamped (hemostat pressure) in various points to evaluate the cutaneous muscle reflexes and thus assure that surgery could be started.
In case there were any signs of pain during surgery $\left(\mathrm{HR}, \mathrm{f}_{\mathrm{R}}\right.$ and arterial pressures up to $10 \%$ above previous measures or movement after noxious stimulus), the propofol CRI would be increased in $0.1 \mathrm{mg} \mathrm{kg}^{-1}$ minute ${ }^{-1}$ each time, in order to maintain an adequate depth of anesthesia for surgery (Gasparini et al., 2009).

At 30 minutes after the epidural anesthesia (T30), beginning of surgery (TS), right or left ovarian pedicle clamping (TPR and TPL respectively), cervix clamping (TC) as well as the start and end of the skin suture (TSu and TESu), the HR was assessed through multiparameter monitoring and the ECG through a TEB system (XX). At those times SAP, MAP and DAP were also invasively assessed through the right metatarsal artery; rectal temperature was assessed with a digital thermometer (BD, Becton Dickinson XX); $\mathrm{f}_{\mathrm{R}}$, oxyhemoglobin saturation $\left(\mathrm{SpO}_{2}\right)$, inspired oxygen fraction $\left(\mathrm{FiO}_{2}\right)$ and end-tidal carbon dioxide tension $\left(\mathrm{P}_{\mathrm{E}}{ }^{\prime} \mathrm{CO}_{2}\right)$ were recorded from the multiparameter monitor; and blood gases were immediately analyzed (Gas analysis apparatus Roche Omni-C, Brazil) from $0.6 \mathrm{~mL}$ of arterial blood drawn directly from the femoral artery into heparinized syringes. Blood samples were obtained at four times: TB, T30, TESu and after total recovery from anesthesia (TR), when animals were standing and showing no signs of ataxia.

Serum cortisol concentrations (Kit Cout-a-Count DPC-Siemens) were performed by radioimmunoassay on venous blood samples collected from the jugular vein at TB, T30, TESu and TR. Plasma concentrations of levobupivacaine and morphine were also assessed from venous blood samples, obtained from the jugular vein into lithium heparin syringes (Monovette, Brazil) at T30, T1h (one hour after epidural), TESu and TR. All analyses were performed at Galeno Research Laboratories, through high performance liquid chromatography (HPLC) coupled to tandem mass spectrometry (Gas Chromatograph ClassLC 10, Shimadzu Corporation, Kyoto, Japan).

The onset time and duration of the blockade were determined according to Albuquerque et al. (2010). Analgesia at the postoperative period was assessed through visual analog scale (VAS) for pain. Whenever supplementary analgesia (rescue analgesia) was required, patients would 
receive $5 \mathrm{mg} \mathrm{kg}^{-1}$ tramadol subcutaneously during evaluations. Animals that were not given rescue analgesia at that period received the same tramadol dose at discharge (Buback et al., 1996; Pibarot et al., 1997; Brondani et al., 2004).

Data were analyzed through ANOVA for repeated measures and error analysis (residual analysis) to verify normality and homogeneity of data variance. All analyses were performed using Statistical Analysis System software (SAS) and significance was considered when $\mathrm{P}<0.05$. For results with normal distribution, we used ANOVA followed by Tukey's test. For non- parametric comparisons between groups we used Kruskal-Wallis. Time measures were compared by Friedman followed by Dunn's multiple comparisons test.

\section{RESULTS}

There were no differences in HR between groups. Arterial pressures were significantly increased at T5 and subsequent measurements in GL (SAP), GL, GLM0.15 and GLM0.2 (MAP); and in all three morphine groups (DAP). Respiratory variables such as $\mathrm{f}_{\mathrm{R}}, \mathrm{SpO}_{2}, \mathrm{FiO}_{2}$ and $\mathrm{P}_{\mathrm{E}}^{\prime} \mathrm{CO}_{2}$ did not vary significantly (Table 1 ).

Table 1. Mean \pm standard deviation of heart rate $(\mathrm{HR})$, respiratory variables $\left(\mathrm{f}_{\mathrm{R}}, \mathrm{SpO}_{2}, \mathrm{FiO}_{2}\right.$ and $\left.\mathrm{P}_{\mathrm{E}}{ }^{\prime} \mathrm{CO}_{2}\right)$ and arterial blood pressures (SAP, MAP and DAP) of bitches undergoing epidural anesthesia with levobupivacaine alone or combined with morphine

\begin{tabular}{|c|c|c|c|c|c|c|c|c|}
\hline \multirow{2}{*}{ Variables } & \multirow{2}{*}{ Groups } & \multicolumn{7}{|c|}{ Times } \\
\hline & & $\mathrm{T} 30$ & TS & TPR & TPL & $\mathrm{TC}$ & $\mathrm{TSu}$ & TESu \\
\hline \multirow{4}{*}{$\begin{array}{c}\text { HR } \\
\text { (beats minute }^{-1} \text { ) }\end{array}$} & $\mathrm{L}$ & $113 \pm 19$ & $112 \pm 20$ & $107 \pm 18$ & $106 \pm 16$ & $107 \pm 14$ & $104 \pm 14$ & $107 \pm 19$ \\
\hline & LM0.1 & $113 \pm 13$ & $105 \pm 18$ & $107 \pm 15$ & $110 \pm 29$ & $116 \pm 23$ & $117 \pm 26$ & $113 \pm 25$ \\
\hline & LM0.15 & $112 \pm 17$ & $120 \pm 22$ & $121 \pm 28$ & $115 \pm 21$ & $126 \pm 27$ & $128 \pm 25$ & $129 \pm 21$ \\
\hline & LM0.2 & $108 \pm 20$ & $111 \pm 21$ & $121 \pm 23$ & $112 \pm 19$ & $115 \pm 23$ & $122 \pm 24$ & $126 \pm 28$ \\
\hline \multirow{4}{*}{$\underset{(\mathrm{mmHg})}{\mathrm{SAP}}$} & $\mathrm{L}$ & $92 \pm 21 \mathrm{c}$ & $90 \pm 16 c$ & $100 \pm 22 b c$ & $121 \pm 19 \mathrm{ab}$ & $108 \pm 16$ & $96 \pm 17 b c$ & $93 \pm 8 c$ \\
\hline & LM0.1 & $96 \pm 15$ & $88 \pm 10$ & $96 \pm 13$ & $104 \pm 11$ & $94 \pm 14$ & $89 \pm 14$ & $91 \pm 9$ \\
\hline & LM0.15 & $101 \pm 19$ & $104 \pm 23$ & $121 \pm 30$ & $127 \pm 29$ & $120 \pm 33$ & $110 \pm 22$ & $102 \pm 15$ \\
\hline & LM0.2 & $95 \pm 15$ & $92 \pm 22$ & $116 \pm 39$ & $117 \pm 26$ & $110 \pm 30$ & $96 \pm 25$ & $90 \pm 25$ \\
\hline \multirow{4}{*}{$\begin{array}{c}\mathrm{MAP} \\
(\mathrm{mmHg})\end{array}$} & $\mathrm{L}$ & $68 \pm 18 c$ & $65 \pm 16 c$ & $83 \pm 23$ & $98 \pm 24 \mathrm{ab}$ & $82 \pm 25$ & $76 \pm 16$ & $71 \pm 13 b c$ \\
\hline & LM0.1 & $69 \pm 23$ & $61 \pm 13$ & $71 \pm 10$ & $79 \pm 8$ & $69 \pm 11$ & $64 \pm 8$ & $69 \pm 12$ \\
\hline & LM0.15 & $73 \pm 19 c$ & $77 \pm 22 b c$ & $93 \pm 28$ & $99 \pm 23 \mathrm{ab}$ & $90 \pm 28$ & $83 \pm 20$ & $76 \pm 11 b c$ \\
\hline & LM0.2 & $69 \pm 15 a$ & $68 \pm 10 c$ & $90 \pm 24 a b$ & $92 \pm 13 \mathrm{a}$ & $82 \pm 15$ & $75 \pm 16$ & $70 \pm 15 b c$ \\
\hline \multirow{4}{*}{$\begin{array}{c}\text { DAP } \\
(\mathrm{mmHg})\end{array}$} & $\mathrm{L}$ & $55 \pm 20 b c$ & $51 \pm 19 \mathrm{c}$ & $68 \pm 21$ & $83 \pm 24 a b$ & $64 \pm 20$ & $60 \pm 22$ & $59 \pm 21$ \\
\hline & LM0.1 & $47 \pm 15$ & $47 \pm 14$ & $56 \pm 9$ & $64 \pm 9$ & $55 \pm 12$ & $49 \pm 8$ & $52 \pm 11$ \\
\hline & LM0.15 & $55 \pm 19 b$ & $62 \pm 23$ & $78 \pm 30$ & $84 \pm 23 a$ & $74 \pm 28$ & $69 \pm 21$ & $61 \pm 13$ \\
\hline & LM0.2 & $52 \pm 14 d$ & $56 \pm 9 \mathrm{bcd}$ & $75 \pm 18 \mathrm{ab}$ & $80 \pm 13 a$ & $69 \pm 11$ & $62 \pm 10$ & $54 \pm 11 \mathrm{~cd}$ \\
\hline \multirow{4}{*}{$\begin{array}{c}\mathrm{f}_{\mathrm{R}} \\
\text { (breaths minute }^{-1} \text { ) }\end{array}$} & $\mathrm{L}$ & $13 \pm 4$ & $14 \pm 6$ & $20 \pm 14$ & $18 \pm 15$ & $15 \pm 10$ & $15 \pm 7$ & $15 \pm 7$ \\
\hline & LM0.1 & $20 \pm 14$ & $20 \pm 12$ & $29 \pm 17$ & $18 \pm 11$ & $12 \pm 10$ & $8 \pm 4$ & $14 \pm 11$ \\
\hline & LM0.15 & $16 \pm 6$ & $20 \pm 11$ & $18 \pm 12$ & $19 \pm 15$ & $12 \pm 11$ & $11 \pm 9$ & $9 \pm 6$ \\
\hline & LM0.2 & $14 \pm 13$ & $14 \pm 8$ & $23 \pm 4$ & $21 \pm 11$ & $12 \pm 12$ & $11 \pm 5$ & $13 \pm 5$ \\
\hline \multirow{4}{*}{$\begin{array}{c}\mathrm{SpO}_{2} \\
(\%)\end{array}$} & $\mathrm{L}$ & $97 \pm 3$ & $98 \pm 2$ & $97 \pm 3$ & $96 \pm 4$ & $99 \pm 1$ & $98 \pm 2$ & $98 \pm 2$ \\
\hline & LM0.1 & $96 \pm 5$ & $98 \pm 2$ & $97 \pm 3$ & $98 \pm 2$ & $98 \pm 2$ & $98 \pm 1$ & $96 \pm 4$ \\
\hline & LM0.15 & $97 \pm 2$ & $97 \pm 2$ & $96 \pm 3$ & $97 \pm 2$ & $97 \pm 2$ & $97 \pm 2$ & $97 \pm 2$ \\
\hline & LM0.2 & $99 \pm 1$ & $98 \pm 1$ & $97 \pm 1$ & $95 \pm 3$ & $96 \pm 3$ & $98 \pm 3$ & $97 \pm 3$ \\
\hline \multirow{4}{*}{$\begin{array}{l}\mathrm{FiO}_{2} \\
(\%)\end{array}$} & $\mathrm{L}$ & $91 \pm 9$ & $93 \pm 6$ & $93 \pm 4$ & $94 \pm 3$ & $95 \pm 2$ & $95 \pm 2$ & $94 \pm 2$ \\
\hline & LM0.1 & $82 \pm 22$ & $86 \pm 20$ & $87 \pm 16$ & $86 \pm 21$ & $87 \pm 21$ & $88 \pm 19$ & $88 \pm 15$ \\
\hline & LM0.15 & $93 \pm 4$ & $95 \pm 2$ & $95 \pm 2$ & $95 \pm 2$ & $94 \pm 4$ & $95 \pm 2$ & $95 \pm 2$ \\
\hline & LM0.2 & $88 \pm 14$ & $91 \pm 10$ & $92 \pm 9$ & $93 \pm 7$ & $94 \pm 3$ & $95 \pm 2$ & $95 \pm 2$ \\
\hline \multirow{4}{*}{$\begin{array}{l}\mathrm{P}_{\mathrm{E}}{ }^{\prime} \mathrm{CO}_{2} \\
(\mathrm{mmHg})\end{array}$} & $\mathrm{L}$ & $50 \pm 12$ & $46 \pm 17$ & $42 \pm 9$ & $46 \pm 7$ & $47 \pm 10$ & $47 \pm 7$ & $43 \pm 10$ \\
\hline & LM0.1 & $42 \pm 6$ & $41 \pm 9$ & $37 \pm 13$ & $41 \pm 6$ & $45 \pm 16$ & $47 \pm 13$ & $41 \pm 9$ \\
\hline & LM0.15 & $50 \pm 17$ & $43 \pm 20$ & $44 \pm 24$ & $39 \pm 13$ & $41 \pm 11$ & $52 \pm 20$ & $55 \pm 13$ \\
\hline & LM0.2 & $45 \pm 19$ & $45 \pm 8$ & $44 \pm 10$ & $43 \pm 8$ & $47 \pm 7$ & $47 \pm 7$ & $49 \pm 8$ \\
\hline
\end{tabular}

Means followed by the same letter in lines do not differ significantly according to Tukey's test $(\mathrm{P}>0.05)$. 
Arterial blood pH gradually decreased (T30 and TESu) in all groups. This decrease accompanied the duration of the epidural and returned close to baseline values at recovery (TR) (Table 2). Values observed in $\mathrm{PaO}_{2}, \mathrm{PaCO}_{2}$ and arterial
$\mathrm{HCO}_{3}{ }^{-}$were increased in T30 and TESu. The $\mathrm{SaO}_{2}$ was higher in GLM0.15 and GLM0.2 and these changes, as well as those in $\mathrm{pH}$, lasted as long as the epidural anesthesia (Table 2).

Table 2. Means \pm standard deviation of blood gases and acid-base variables of bitches undergoing epidural anesthesia with levobupivacaine alone or combined with morphine

\begin{tabular}{|c|c|c|c|c|c|}
\hline \multirow{2}{*}{ Variables } & \multirow{2}{*}{ Groups } & \multicolumn{4}{|c|}{ Times } \\
\hline & & TB & $\mathrm{T} 30$ & TESu & TR \\
\hline \multirow{4}{*}{$\mathrm{pH}$} & $\mathrm{L}$ & $7.364 \pm 0.053 a$ & $7.255 \pm 0.064 b$ & $7.250 \pm 0.064 b$ & $7.376 \pm 0.029 a$ \\
\hline & LM0.1 & $7.375 \pm 0.023 a$ & $7.289 \pm 0.055 b$ & $7.244 \pm 0.079 b$ & $7.373 \pm 0.021 \mathrm{a}$ \\
\hline & LM0.15 & $7.347 \pm 0.067 a$ & $7.242 \pm 0.090 b$ & $7.206 \pm 0.083 b$ & $7.360 \pm 0.027 a$ \\
\hline & LM0.2 & $7.356 \pm 0.029 a$ & $7.286 \pm 0.060 \mathrm{~b}$ & $7.249 \pm 0.069 b$ & $7.368 \pm 0.015 a$ \\
\hline \multirow{4}{*}{$\mathrm{PaO}_{2}(\mathrm{mmHg})$} & $\mathrm{L}$ & $95.5 \pm 25.6 b$ & $380.0 \pm 69.9 \mathrm{a}$ & $378.4 \pm 122.0 \mathrm{a}$ & $93.0 \pm 18.4 b$ \\
\hline & LM0.1 & $102.2 \pm 21.4 b$ & $291.1 \pm 114.2 \mathrm{a}$ & $339.8 \pm 174.4 \mathrm{a}$ & $85.0 \pm 29.0 \mathrm{~b}$ \\
\hline & LM0.15 & $105.3 \pm 17.9 b$ & $321.2 \pm 110.0 \mathrm{a}$ & $336.6 \pm 122.5 a$ & $96.2 \pm 13.5 b$ \\
\hline & LM0.2 & $83.3 \pm 24.0 \mathrm{~b}$ & $302.6 \pm 112.2 \mathrm{a}$ & $412.3 \pm 127.0 \mathrm{a}$ & $104.6 \pm 2.0 \mathrm{~b}$ \\
\hline \multirow{4}{*}{$\mathrm{PaCO}_{2}(\mathrm{mmHg})$} & $\mathrm{L}$ & $35.3 \pm 11.4 b$ & $51.8 \pm 9.2 \mathrm{a}$ & $50.7 \pm 9.8 \mathrm{a}$ & $33.6 \pm 4.3 b$ \\
\hline & LM0.1 & $34.6 \pm 4.8 \mathrm{c}$ & $47.5 \pm 9.1 \mathrm{ab}$ & $53.0 \pm 13.9 \mathrm{ab}$ & $35.1 \pm 5.7 b c$ \\
\hline & LM0.15 & $33.9 \pm 4.1 b$ & $57.1 \pm 17.0 \mathrm{a}$ & $60.2 \pm 16.0 \mathrm{a}$ & $34.2 \pm 3.8 \mathrm{~b}$ \\
\hline & LM0.2 & $37.5 \pm 4.4 \mathrm{~b}$ & $47.0 \pm 5.3 \mathrm{a}$ & $54.3 \pm 13.7 \mathrm{a}$ & $36.5 \pm 3.1 \mathrm{~b}$ \\
\hline \multirow{4}{*}{$\mathrm{HCO}_{3}^{-}\left(\mathrm{mmol} \mathrm{L}{ }^{-1}\right)$} & $\mathrm{L}$ & $18.8 \pm 3.6 b$ & $22.0 \pm 1.3 \mathrm{a}$ & $21.4 \pm 1.6$ & $19.0 \pm 1.8 b$ \\
\hline & LM0.1 & $19.4 \pm 2.5 b$ & $22.1 \pm 2.7 \mathrm{a}$ & $22.1 \pm 2.5 \mathrm{a}$ & $19.7 \pm 3.2 b$ \\
\hline & LM0.15 & $17.8 \pm 2.2 b$ & $23.2 \pm 2.0 \mathrm{a}$ & $22.8 \pm 2.5 \mathrm{a}$ & $18.8 \pm 1.4 b$ \\
\hline & LM0.2 & $20.2 \pm 2.4 b$ & $22.5 \pm 1.3 \mathrm{a}$ & $22.8 \pm 1.5 \mathrm{a}$ & $20.3 \pm 1.5 b$ \\
\hline \multirow{4}{*}{$\mathrm{SaO}_{2}(\%)$} & $\mathrm{L}$ & $91.3 \pm 15.5$ & $99.9 \pm 0.1$ & $99.5 \pm 1.2$ & $95.2 \pm 4.4$ \\
\hline & LM0.1 & $94.6 \pm 8.4$ & $99.5 \pm 0.8$ & $98.4 \pm 3.1$ & $91.4 \pm 8.9$ \\
\hline & LM0.15 & $96.2 \pm 1.9 b$ & $99.0 \pm 1.5 \mathrm{a}$ & $99.7 \pm 0.5 \mathrm{a}$ & $95.6 \pm 3.0 \mathrm{~b}$ \\
\hline & LM0.2 & $92.0 \pm 5.6 \mathrm{~b}$ & $97.2 \pm 4.0 \mathrm{a}$ & $99.7 \pm 0.6 \mathrm{a}$ & $97.0 \pm 1.1$ \\
\hline
\end{tabular}

Means followed by the same letter in lines do not differ significantly according to Tukey's test $(\mathrm{P}>0.05)$.

Serum cortisol levels were lower at TB, T30 and TR than at TESu (end of the surgical procedure) in GL. This difference was also observed between TESu and T30 in GLM0.1. TESu was also statistically different between GL and the three morphine groups (GLM0.1, GLM0.15 and GLM0.2) (Table 3).

Plasma morphine and levobupivacaine levels can be seen in Table 3 and remained assessable for as long as the epidural lasted.

The longest onset time, assessed by the paw withdrawal reflex, was of $2.5 \pm 0.5$ minutes in GLM0.1. The longest duration of epidural anesthesia (up to $537 \pm 183$ minutes) happened in the same group (Table 4).
Propofol CRI started at $0.4 \mathrm{mg} \mathrm{kg}^{-1}$ minute $^{-1}$ in all subjects and adjustments were made according to each dog's requirements. Variation happened over the study and the highest rate was $0.7 \mathrm{mg} \mathrm{kg}^{-}$ ${ }^{1}$ minute $^{-1}$ in GL and GLM0.1 (12.5 and 37.5\% respectively).

Moreover, a few adverse effects due to the epidural anesthesia were observed, such as limb spasticity (12.5\% of the subjects in GL), muscle tremors and opisthotonos $(12.5 \%$ of the subjects in GLM0.15), diarrhea ( $25 \%$ of the subjects in GLM0.1), vomiting (12.5\% of the subjects in GL and GLM0.1) and the Schiff-Sherrington phenomenon (12.5\% of the subjects in GLM0.2). 
Table 3. Means \pm standard deviation of serum cortisol levels and plasma morphine and levobupivacaine levels of bitches undergoing epidural anesthesia with levobupivacaine alone or combined with morphine

\begin{tabular}{|c|c|c|c|c|c|}
\hline \multirow{2}{*}{ Variables } & \multirow{2}{*}{ Groups } & \multicolumn{4}{|c|}{ Times } \\
\hline & & TB & T30 & TESu & TR \\
\hline \multirow{4}{*}{ Serum cortisol $\left(\mu \mathrm{gdL}^{-1}\right)$} & $\mathrm{L}$ & $10.8 \pm 5.9 \mathrm{a}$ & $5.9 \pm 2.7 \mathrm{a}$ & $20.6 \pm 12.7 b$ & $5.2 \pm 3.8 \mathrm{a}$ \\
\hline & LM0.1 & $6.6 \pm 3.3$ & $4.3 \pm 3.3 \mathrm{a}$ & $12.3 \pm 4.8 b$ & $6.5 \pm 4.1$ \\
\hline & LM0.15 & $9.5 \pm 4.0$ & $5.1 \pm 3.7$ & $11.5 \pm 6.7$ & $5.9 \pm 2.1$ \\
\hline & LM0.2 & $9.1 \pm 4.8$ & $5.5 \pm 3.6$ & $12.6 \pm 4.7$ & $6.3 \pm 3.9$ \\
\hline \multirow{2}{*}{ Variables } & \multirow{2}{*}{ Groups } & \multicolumn{4}{|c|}{ Times } \\
\hline & & $\mathrm{T} 30$ & T1h & TESu & TR \\
\hline \multirow{3}{*}{ Plasma morphine $\left(\mathrm{ngdL}^{-1}\right)$} & LM0.1 & $20.4 \pm 6.8 \mathrm{a}$ & $10.9 \pm 2.8 b$ & $7.4 \pm 2.1 \mathrm{~b}$ & $0.2 \pm 0.1 \mathrm{c}$ \\
\hline & LM0.15 & $24.6 \pm 10.3 \mathrm{a}$ & $14.5 \pm 7.7 b$ & $10.5 \pm 5.9 b$ & $0.5 \pm 0.2 \mathrm{c}$ \\
\hline & LM0.2 & $54.1 \pm 15.0 \mathrm{a}$ & $29.4 \pm 7.5 b$ & $22.1 \pm 7.3 b$ & $0.9 \pm 1.4 \mathrm{c}$ \\
\hline \multirow{4}{*}{ Plasma levobupivacaine $\left(\operatorname{ngdL}^{-1}\right)$} & $\mathrm{L}$ & $577.4 \pm 307.6 \mathrm{a}$ & $462.1 \pm 284.8 \mathrm{ab}$ & $381.0 \pm 198.4 b$ & $138.1 \pm 140.5 c$ \\
\hline & LM0.1 & $603.0 \pm 348.5 \mathrm{a}$ & $441.1 \pm 247.0 \mathrm{ab}$ & $351.5 \pm 196.3 b$ & $100.4 \pm 86.7 \mathrm{c}$ \\
\hline & LM0.15 & $703.0 \pm 470.4 \mathrm{a}$ & $493.8 \pm 344.2 \mathrm{ab}$ & $420.1 \pm 350.5 b$ & $100.3 \pm 86.6 \mathrm{c}$ \\
\hline & LM0.2 & $491.3 \pm 69.6 \mathrm{a}$ & $356.1 \pm 57.4 b$ & $285.1 \pm 46.7 \mathrm{c}$ & $63.3 \pm 18.3 d$ \\
\hline
\end{tabular}

Means followed by the same letter in lines do not differ significantly according to Tukey's test $(\mathrm{P}>0.05)$.

Table 4. Means \pm standard deviation of onset time and duration of anesthesia in bitches undergoing epidural anesthesia with levobupivacaine alone or combined with morphine

\begin{tabular}{ccccc}
\hline \multirow{2}{*}{ Variables } & \multicolumn{4}{c}{ Onset (minutes) } \\
\cline { 2 - 5 } & $\mathrm{L}$ & LM0.1 & LM0.15 & LM0.2 \\
\hline Anal reflex & $1,3 \pm 0.5$ & $1.8 \pm 0.5 \mathrm{a}$ & $1.0 \pm 0.0 \mathrm{~b}$ & $1.1 \pm 0.4$ \\
Tail muscle tone & $1.3 \pm 0.5$ & $1.6 \pm 0.5 \mathrm{a}$ & $1.0 \pm 0.0 \mathrm{~b}$ & $1.0 \pm 0.0 \mathrm{~b}$ \\
Paw with drawal reflex & $2.0 \pm 0.8$ & $2.5 \pm 0.5$ & $1.8 \pm 0.5$ & $1.8 \pm 0.5$ \\
Muscle tone & $1.6 \pm 0.5$ & $2.0 \pm 0.5 \mathrm{a}$ & $1.0 \pm 0.0 \mathrm{~b}$ & $1.3 \pm 0.5$ \\
\hline Variables & $\mathrm{L}$ & LM0.1 & LM0.15 & LM0.2 \\
\hline Resumption of anal sphincter tone & $321 \pm 152$ & $323 \pm 141$ & $312 \pm 122$ & $339 \pm 144$ \\
Resumption of tail muscle tone & $326 \pm 134$ & $367 \pm 139$ & $336 \pm 132$ & $301 \pm 125$ \\
Resumption of paw withdrawal reflex & $463 \pm 173$ & $500 \pm 137$ & $495 \pm 142$ & $437 \pm 166$ \\
Normal mobility & $442 \pm 150$ & $537 \pm 183$ & $501 \pm 93$ & $503 \pm 176$
\end{tabular}

Means followed by the same letter in lines do not differ significantly according to Tukey's test $(\mathrm{P}>0.05)$.

\section{DISCUSSION}

Heart rate and arterial blood pressures were the most expected variables to change due to the higher doses of morphine.

The heart rate was within acceptable limits throughout the study in all subjects. Similar findings have been reported after administration of morphine $\left(0.1 \mathrm{mg} \mathrm{kg}^{-1}\right)$ and sodium chloride $(0.9 \% \mathrm{NaCl})$ epidurally in bitches resulting in cardiovascular stability (Pereira and Marques, 2009). Lawal and Adetunji (2009) have compared the effects of epidural bupivacaine $\left(1 \mathrm{mg} \mathrm{kg}^{-1}\right)$, lidocaine $\left(4 \mathrm{mg} \mathrm{kg}^{-1}\right)$ or lidocaine $\left(0.5 \mathrm{mg} \mathrm{kg}^{-1}\right)$ combined with bupivacaine $(0.5 \mathrm{mg}$ $\mathrm{kg}^{-1}$ ) in cats. No significant cardiac changes were observed, similarly to the levobupivacaine alone.

However, Silva et al. (2004) have observed different results, with severe bradycardia after epidural morphine at $0.1 \mathrm{mg} \mathrm{kg}^{-1}$. Leone et al. (2009) have reported that local anesthetics of longer duration, such as levobupivacaine and bupivacaine, may cause a dose-dependent prolongation of cardiac conduction, which leads to increased PR and QRS intervals at the electrocardiogram. This was not observed in this study.

Arterial blood pressure increased at TPL, TPR and TC. Due to that increase, rescue analgesia 
was carried out and propofol infusion rates were elevated. However, in one study comparing levobupivacaine to racemic bupivacaine and to $50 \%$ enantiomeric excess bupivacaine in humans undergoing low abdomen surgery, a decrease in SAP has been observed (Tanaka et al., 2005). Levobupivacaine alone has been shown to decrease MAP in humans during elective surgeries (Glaser et al., 2002), whereas hemodynamic stability has been described in women undergoing epidural anesthesia for cesarean-section as well as in their newborns (Bergamaschi et al., 2005).

We ascribe the increases in blood pressure to the noxious stimulus caused by surgery, given that those values were normal at the end of the procedure. Additionally, blood pressure was increased by ovarian pedicle and cervix clamping. Campoy et al. (2012) have reported similar results in dogs undergoing sciatic and femoral nerve blockade with bupivacaine together with epidurally administered morphine.

Body temperature was expected to decline probably due to the epidural, systemic absorption and central nervous system delivery of the anesthetic through the cerebrospinal fluid (Sessler and Ponte, 1990). A similar study by Cassu et al. (2008) has shown that, after epidural injection of lidocaine alone or combined with fentanyl, temperature gradually decreased, but there was no clinical relevance to it. Furthermore, we cannot discard the influence of propofol, administered through constant rate infusion, on body temperature, which has been described in dogs (Ferro et al., 2005).

Respiratory variables have been shown to be greatly altered by morphine (Valadão et al., 2002; Silva et al., 2004; Pereira and Marques, 2009), however, our results showed stability of the studied parameters $\left(f_{\mathrm{R}}, \mathrm{SpO}_{2}, \quad \mathrm{FiO}_{2}\right.$ e $\mathrm{P}_{\mathrm{E}}{ }^{\prime} \mathrm{CO}_{2}$ ). Yaksh et al. (2000) corroborates these results for having observed minimal changes in respiratory variables after epidural administration of morphine at $5 \mathrm{mg}$ in $0.9 \%$ sodium chloride.

The decreases found in arterial $\mathrm{pH}$, together with increased $\mathrm{PaCO}_{2}$ and arterial $\mathrm{HCO}_{3}^{-}$suggest that epidural anesthesia caused transient respiratory acidosis. Normal values were reached at the end of the study.
The high values of $\mathrm{PaO}_{2}$ and $\mathrm{SaO}_{2}$ found are related to $100 \%$ oxygen delivered through the anesthetic circuit (MP30 and TESu). Also, the increase in those variables compensated the hypoventilation which was probably the cause of increased $\mathrm{PaCO}_{2}$.

The high $\mathrm{PaO}_{2}$ and $\mathrm{SaO}_{2}$ were ascribed to $100 \%$ oxygen delivered by the rebreathing circuit. Furthermore, increases in those variables contributed for compensating hypoventilation, which caused high $\mathrm{PaCO}_{2}$ values. When comparing epidurally administered tramadol with morphine in dogs, Baraka et al. (1993) have reported significant respiratory changes such as decreased $f_{R}$ and $\mathrm{PaO}_{2}$ without variations in $\mathrm{PaCO}_{2}$ when morphine was used. In one retrospective study of 242 dogs and 23 cats, epidural anesthesia with morphine with or without bupivacaine has been associated with respiratory alterations that decreased $\mathrm{P}_{\mathrm{E}}{ }^{\prime} \mathrm{CO}_{2}$ and increased $\mathrm{PaCO}_{2}$ (Troncy et al., 2002). On the other hand, propofol is known to cause respiratory depression, which will result in high $\mathrm{PaCO}_{2}$ values (Ferro et al., 2005). According to the same author, this is an effect directly related to the infusion rate. However, in our study the CRI did not exceed $0.7 \mathrm{mg} \mathrm{kg}^{-1}$ minute ${ }^{-1}$, which is considered a regular rate for dogs undergoing surgery (Gasparini et al., 2009).

Serum cortisol is an important clinical variable that changes in circadian rhythm, with high levels in the morning and lower levels at the end of the day, which justifies the choice for carrying the procedures early in the morning for all subjects. According to Caldeira et al. (2006), serum cortisol dosage is important, appropriate and useful for identifying the moments of major surgical stress during ovariohysterectomy. The increases observed in this study coincided precisely with the measure subsequent to the major stimulus (TESu) and confirmed the relevance of assessing those levels.

Additionally, we observed decreased cortisol levels in the morphine groups when compared to GL. Lower serum cortisol has been described in dogs after morphine administration (Pereira and Marques, 2009). Sibanda et al. (2006) have also observed reduced neuroendocrine response to stress in dogs that received morphine and bupivacaine epidurally. 
The morphine and levobupivacaine curves behaved similarly to one another. Levels decreased along with the duration of local anesthesia as described by Silva et al. (2004), who observed gradual reduction of morphine levels after subarachnoid administration of 0.1 , $0.3,0.5$ and $1 . \mu \mathrm{g}$ in rats. The authors found serum morphine concentrations of $7.38,114.26$,

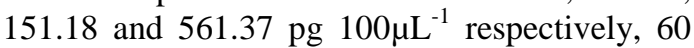
minutes after injection. In this study, at 60 minutes after epidural anesthesia those concentrations were of $10.9,14.5$ and $29.4 \mathrm{ng}$ $\mathrm{mL}^{-1}$ respectively in GLM0.1, GLM0.15 and GLM0.2.

Moreover, at 30 minutes after the epidural (T30) in GLM0.15 morphine levels were high $\left(24.6 \pm 10.3 \mathrm{ng} \mathrm{mL} \mathrm{mL}^{-1}\right)$ and when the epidural blockade ended (approximately at 500 minutes) those levels could barely be detected $(0.5 \pm 0.2 \mathrm{ng}$ $\left.\mathrm{mL}^{-1}\right)$. The findings in this study are similar to one study in dogs that received $5 \mathrm{mg}$ of morphine epidurally. Cerebrospinal concentrations were rapidly increased followed by exponential decrease (Yaksh et al., 2000).

The results of this study are similar to those of Oliveira et al. (2011), who have observed low plasma concentrations of $50 \%$ enantiomeric excess bupivacaine between days 2 and 8 after sciatic nerve block in rats. We can assume that the doses of morphine used in this study via the epidural route did not influence the onset of blockades clinically, seeing that means are similar between groups. Likewise, in guinea pigs levobupivacaine has provided sensitive and motor blockades shortly after the epidural injection (Vasconcelos Filho et al., 2008).

Long periods of action were observed with the drugs in this study, both with levobupivacaine alone and its combination with morphine. Similar to these results, Leone et al. (2009) have also reported long periods of action with the use of levobupivacaine and bupivacaine. Previous studies, however, describe shorter motor blockade when comparing levobupivacaine to bupivacaine in women undergoing abdominal surgery (Tanaka et al., 2005). In dogs, sensitive and motor blockades up to 292 and 360 minutes, respectively, have been demonstrated with $0.75 \%$ levobupivacaine (Segura et al., 2009). Such results are slightly above the usually reported, but nevertheless below the findings of this study.

Finally, a few adverse effects due to epidural anesthesia were observed in the present study, which corroborate studies by Troncy et al. (2002) and Fowler et al. (2008) who describe hardly any adverse reactions and low incidence of late onset complications after the procedures. Vomiting, dysphoria and sedation have been described by Kukanich et al. (2005) after intravenous morphine in dogs. Of these complications, only vomiting was observed in some subjects in this study.

\section{CONCLUSIONS}

Levobupivacaine alone or combined with morphine at $0.1,0.15$ or $0.2 \mathrm{mg} \mathrm{kg}^{-1}$ via the epidural route has allowed for elective ovariohysterectomy to be performed in bitches with minimal cardiovascular and serum cortisol variations, as well as minimal adverse effects. Local anesthesia in all four groups was sufficient to maintain minimum propofol infusion rates in all subjects.

\section{REFERENCES}

ALBUQUERQUE, V.B.; SOUZA, T.B.F.; VIVAN, M.C.R. et al. Influência do butorfanol sobre os períodos de latência e de ação da ropivacaína pela via peridural na ovariossalpingo-histerectomia em cadelas. Arq. Bras. Med. Vet. Zootec., v.62, p.806-811, 2010.

BARAKA, A.; JABBOUR, S.; GHABASH, M. et al. A comparison of epidural tramadol and epidural morphine for postoperative analgesia. Can. J. Anaesth., v.40, p.308-313, 1993.

BERGAMASCHI, B.; BALLE, V.R.; GOMES, M.E.W. et al. Levobupivacaína versus bupivacaína em anestesia peridural para cesarianas. Estudo comparativo. Rev. Bras. Anestesiol., v.55, p.606-613, 2005.

BRONDANI, J.T.; NATALINI, C.C.; RAISER, A.G. et al. Analgesia epidural com clonidina ou romifidina em cães submetidos à cirurgia coxofemoral. Arq. Bras. Med. Vet. Zootec., v.56, p.175-182, 2004. 
BUBACK, J.L.; BOOTHE, H.W.; CARROL, G.L. Comparasion of three methods for relief of pain after ear canal ablation in dogs. Vet. Surg., v.25, p.380-385, 1996.

CALDEIRA, F.M.C.; OLIVEIRA, H.P.; MELO, E.G. et al. Cortisol sérico e glicemia em cadelas tratadas com tramadol e submetidas a ováriohisterectomia. Ciênc. Rural, v.36, p.155-160, 2006.

CAMPOY, L.; MARTIN-FLORES, M.; LUDDERS, J.W. et al. Comparison of bupivacaine femoral and sciatic nerve block versus bupivacaine and morphine epidural for stifle surgery in dogs. Vet. Anaesth. Analg., v.39, p.91-98, 2012.

CASSU, R.N.; STEVANIN, H.; KANASHIRO, C. et al. Anestesia epidural com lidocaína isolada e associada ao fentanil para realização de ovariossalpingo-histerectomia em cadelas. Arq. Bras. Med. Vet. Zootec., v.60, p.825-831, 2008.

FERRO, P.C.; NUNES, N.; PAULA, D.P. et al. Variáveis fisiológicas em cães submetidos à infusão contínua de diferentes doses de propofol. Ciênc. Rural, v.35, p.1003-1008, 2005.

FOWLER, S.J.; SYMONS, J.; SABATO, S.; MYLES, P.S. Epidural analgesia compared with peripheral nerve blockade after major knee surgery: a systematic review and meta-analysis of randomized trials. Br. J. Anaesth., v.100, p.154-164, 2008.

GASPARINI, S.S.; LUNA, S.P.L.; CASSU, R.N.; BIASI, F. Anestesia intravenosa total utilizando propofol ou propofol/cetamina em cadelas submetidas a ovariossalpingohisterectomia. Ciênc. Rural, v.39, p.1438-1444, 2009.

GLASER, C.; MARHOFER, P.; ZIMPFER, G. et al. Levobupivacaine versus racemic bupivacaine for spinal anesthesia. Anesth. Analg., v.94, p.194-198, 2005.

KUKANICH, B.; LASCELLES, B.D.X.; PAPICH, M.G. Pharmacokinetics of morphine and plasma concentrations of morphine-6glucuronide following morphine administration to dogs. J. Vet. Pharmacol. Therap., v.28, p.371$376,2005$.
LAWAL, F.M.; ADETUNJI, A. A comparison of epidural anaesthesia with lignocaine, bupivacaine and a lignocaine-bupivacaine mixture in cats. J. S. Afr. Vet. Assoc., v.80, p.243-246, 2009.

LEONE, S.; CIANNI, S.D.; CASATI, A.; FANELLI, G. Pharmacology, toxicology, and clinical use of new long acting local anesthetics, ropivacaine and levobupivacaine. Acta. Biomed., v.79, p.92-105, 2009.

LUCAS, A.N.; FIRTH, A.M.; ANDERSON, G.A. et al. Comparison of the effects of morfhine administered by constant-rate intravenous infusion or intermittent intramuscular injection in dogs. J. Am. Vet. Med. Assoc., v.218, p.884-890, 2001.

OLIVEIRA, R.M.; TANAKA, P.P.; TENÓRIO, S.B. Avaliação do uso de microesferas de bupivacaína em excesso enantiomérico de $50 \%$ após bloqueio do nervo ciático de ratos. Rev. Bras. Anestesiol., v.61, p.736-747, 2011.

PEREIRA, D.A.; MARQUES, J.A. Uso de morfina, xilazina e meloxicam para o controle da dor pós-operatória em cadelas submetidas à ovariossalpingo-histerectomia. Arq. Bras. Med. Vet. Zootec., v.61, p.353-361, 2009.

PIBAROT, P.; DUPUIS, J.; GRISNEAUX, E. et al. Comparison of ketoprofen, oxymorphone, and butorphanol in the treatment of postoperative pain in dogs. J. Am. Vet. Med. Assoc., v.211, p.438-444, 1997.

SANTOS, A.C.; DEARMAS, P.I. Systemic toxicity of levobupivacaine, bupivacaine, and ropivacaine during continuous intravenous infusion to nonpregnant and pregnant ewes. Anesthesiology, v.95, p.1256-1264, 2001.

SAS Institute Inc., SAS OnlineDoc®, Version 8, Cary, NC: SAS Institute Inc., 1999.

SEGURA, I.A.G.; MENAFRO, A.; GARCÍAFERNÁNDEZ, P. et al. Analgesic and motorblocking action of epidurally administered levobupivacaine or bupivacaine in the conscious dog. Vet. Anaesth. Analg., v.36, p.485-494, 2009.

SESSLER, D.I.; PONTE, J. Shevering during epidural anesthesia. Anesthesiology, v.72, p.816$821,1999$. 
SIBANDA, S.; HUGHES, J.M.L.; PAWSON, P.E. et al. The effects of preoperative extradural bupivacaine and morphine on the stress response in dogs undergoing femoro-tibial joint sugery. Vet. Anaesth. Analg., v.33, p.246-257, 2006.

SILVA, N.S.F.; SAKATA, R.K.; ISSY.; A,M. Correlação entre concentração liquórica e efeitos colaterais após injeção de morfina por via subaracnoidea em ratos. Rev. Bras. Anestesiol., v.54, p.53-59, 2004.

TANAKA, P.P.; OGLEARI, M.; VALMORBIDA, P.; TANAKA, M.A.A. Estudo comparativo entre soluções a $0,5 \%$ de levobupivacaína, bupivacaína em excesso enantiomérico de $50 \%$ e bupivacaína racêmica em anestesia peridural para cirurgia de abdômen inferior. Rev. Bras. Anestesiol., v.55, p.597-605, 2005.

TRONCY, E.; JUNOT, S.; KEROACK, S. et al. Results of preemptive epidural administration of morphine with or without bupivacaine in dogs and cats undergoing surgery: 265 cases (19971999). J. Am. Vet. Med. Assoc., v.221, p.666672, 2002.
VALADÃO, C.A.A.; MAZZEI, S.; OLESKOVIEZ, $\mathrm{N}$. Injeção epidural de morfina ou cetamina em cães: avaliação do efeito analgésico pelo emprego de filamentos de Von Frey. Arq. Bras. Med. Vet. Zootec., v.54, p.383-389, 2002.

VASCONCELOS FILHO, P.O.; POSSO, I.P.; CAPELOZZI, M.; CAPELOZZI, V.L. Comparação das alterações histológicas da medula espinal e neurológicas de cobaias após anestesia subaracnoidea com grandes volumes de bupivacaína racêmica, de mistura com excesso enantiomérico de 50\% de bupivacaína (S75-R25) e de levobupivacaína. Rev. Bras. Anestesiol., v.58, p.234-245, 2008.

VLADIMIROV, M.; NAU, C.; MOK, W.N.; STRICHARTZ, G. Potency of bupivacaine stereoisomers tested in vitro and in vivo. Anesthesiology, v.93, p.744-755, 2000.

YAKSH, T.L.; PROVENCHER, J.C.; RATHBUN M.L.; KOHN, F.R. Pharmacokinetics and efficacy of epidurally delivered sustained-release encapsulated morphine in dogs. Anesthesiology, v.90, p.1402-1412, 2000. 